\title{
Strategies in Financial Services, the Shareholders and the System Is Bigger and Broader Better?
}

\author{
Ingo Walter \\ New York University*
}

The classic structure-conduct-performance approach to industrial organization centers on three questions. First, why is does an industry look the way it does, in terms of numbers of competitors, market share distribution and various other metrics? Second, how do firms actually compete, in terms the formation of prices, product and service quality, rivalry and collaboration within and across strategic groups, and other attributes of economic behavior? And third, how does the industry perform for its shareholders, its employees, its clients and suppliers, and within the context the system as a whole in terms of its impact on income and growth, stability, and possibly less clearly defined ideas about such things as social equity? In the financial services industry, these same questions have attracted more than the normal degree of attention. The industry is "special" in a variety of ways, including the fiduciary nature of the business, its role at the center of the payments and capital allocation process with all its static and dynamic implications for economic performance, and the systemic nature of problems that can arise in the industry. So the structure, conduct and performance of the industry has unusually important public interest dimensions.

One facet of the discussion has focused on size of financial firms, however measured, and the range of activities conducted by them. Exhibit 1 depicts a taxonomy of broad-gauge financial services businesses. What are the strategic opportunities and competitive consequences of deepening and broadening a firm's business within and between the four sectors and eight sub-sectors? Is size positively related to total returns

\footnotetext{
${ }^{*}$ Paper presented at a Brookings Institution conference on "Does the Future Belong to Financial Conglomerates?" a joint US-Netherlands Roundtable on Financial Service Conglomerates, Washington, D.C., 24-25 October 2002. Draft of September 19, 2002.
} 
to shareholders? If so, does this involve gains in efficiency or transfers of wealth to shareholders from other constituencies, or maybe both? Does greater breadth generate sufficient information-cost and transaction-cost economies to be beneficial to shareholders and customers, or can it work against their interests in ways that may ultimately impede shareholder value as well? And what about the "specialness," notably the industry's fiduciary character and systemic risk -- is bigger and broader also safer?

This paper begins with a simple strategic framework for thinking about these issues from the perspective of the management of financial firms. What should they be trying to do, and how does this relate to the issues of size and breadth? It then reviews the available evidence and reaches a set of tentative conclusions from what we know so far, both from a shareholder perspective and that of the financial system as a whole.

\section{A Simple Strategic Schematic}

Exhibit 2 is a depiction of the market for financial services as a matrix of clients, products and geographies. [Walter, 1988] Financial firms clearly will want to allocate available financial, human and technological resources to those cells (market segments) in the matrix that promise to throw-off the highest risk-adjusted returns. ${ }^{1}$ In order to do this, they will have to appropriately attribute costs, returns and risks to specific cells in the matrix. And the cells themselves have to be linked-together in a way that maximizes what practitioners and analysts commonly call "synergies."

- $\quad$ Client-driven linkages exist when a financial institution serving a particular client or client-group can, as a result, supply financial services either to the same client or to another client in the same group more efficiently in the same or different geographies. Risk-mitigation results from spreading exposures across clients, along with greater earnings stability to the extent that income streams from different clients or client-segments are not perfectly correlated.

- $\quad$ Product-driven linkages exist when an institution can supply a particular financial service in a more competitive manner because it is already producing the same or a similar financial service in different client or arena dimensions. Here again, there is risk mitigation to the extent that net revenue streams from different products are not perfectly correlated.

\footnotetext{
${ }^{1}$ Much of the following discussion relies on Walter [2003].
} 
- Geographic linkages are important when an institution can service a particular client or supply a particular service more efficiently in one geography as a result of having an active presence in another geography. Once more, the risk profile of the firm may be improved to the extent that business is spread across different currencies, macroeconomic and interest-rate environments.

To extract maximum returns from the market matrix, firms need to understand the competitive dynamics of specific segments as well as, the costs - including acquisition and integration costs in the case of M\&A initiatives - and the risks imbedded in the overall portfolio of activities. Especially challenging is the task of optimizing the linkages between the cells to maximize potential joint cost and revenue economies, as discussed below. Firms that do this well can be considered to have a high degree of "strategic integrity" and should have a market capitalization that exceeds their standalone value of their constituent businesses.

So is bigger and broader better in the financial services industry? If so, why? And what is the evidence? Here we shall consider each of the major arguments, pro and con.

\section{Economies and Diseconomies of Scale}

Whether economies or diseconomies of scale exist in financial services has been at the heart of strategic and regulatory discussions about optimum firm size in the financial services industry. Are larger firms associated with increased scale economies and hence profitability and shareholder value? Can increased average size of firms create a more efficient financial sector? Answers are not easy to find, because they have to isolate the impact of pure size of the production unit as a whole from all of the other revenue and cost impacts of size, discussed below.

In an information- and transactions-intensive industry with frequently high fixed costs such as financial services, there should be ample potential for scale economies. However, the potential for diseconomies of scale attributable to disproportionate increases in administrative overhead, management of complexity, agency problems and other cost factors could also occur in very large financial services firms. If economies of 
scale prevail, increased size will help create financial efficiency and shareholder value. If diseconomies prevail, both will be destroyed. Scale-effects should be directly observable in cost functions of financial services firms and in aggregate performance measures.

Many studies of economies of scale have been undertaken in the banking, insurance and securities industries over the years -- see Saunders [2000] for a survey. Unfortunately, examinations of both scale and scope economies in financial services are unusually problematic. The nature of the empirical tests used, the form of the cost functions, the existence of unique optimum output levels, and the optimizing behavior of financial firms all present difficulties. Limited availability and conformity of data present serious empirical issues. And the conclusions of any study that has detected (or failed to detect) economies of scale and/or scope in a sample of financial institutions does not necessarily have general applicability. Nevertheless, the impact on the operating economics (production functions) of financial firms is so important that available empirical evidence is central to the whole argument.

Estimated cost functions form the basis most of the available empirical tests. Virtually all of them have found that economies of scale are achieved with increases in size among small commercial banks (below $\$ 100$ million in asset size). A few studies have shown that scale economies may also exist in banks falling into the $\$ 100$ million to $\$ 5$ billion range. There is very little evidence so far of scale economies in the case of banks larger than $\$ 5$ billion. More recently, there is some scattered evidence of scalerelated cost gains for banks up to $\$ 25$ billion in asset size. [Berger and Mester, 1997] But according to a survey of all empirical studies of economies of scale through 1998, there was no evidence of such economies among very large banks. Berger, Demsetz and Strahan [1998] and Berger, Hunter, and Timme [1993] found the relationship between size and average cost to be U-shaped. This suggests that small banks can benefit from economies of scale, but that large banks seem to suffer from diseconomies of scale, resulting in higher average costs as they increase in size. The consensus seems to be that scale economies and diseconomies generally do not result in more than about $5 \%$ difference in unit costs. Inability to find major economies of scale among 
large financial services firms is also true of insurance companies [Cummins and $\mathrm{Zi}$, 1998] and broker-dealers [Goldberg, Hanweck, Keenan and Young, 1991]. Lang and Wetzel [1998] found diseconomies of scale in both banking and securities services among German universal banks.

Except for the very smallest among banks and nonbank financial firms, scale economies seem likely to have relatively little bearing on competitive performance. This is particularly true since smaller institutions are sometimes linked-together in cooperatives or other structures that allow harvesting available economies of scale centrally, or are specialists in specific market-segments in Exhibit 2 that are not particularly sensitive to relatively small cost differences that seem to be associated with economies of scale in the financial services industry. A basic problem is that most of the available empirical studies focus entirely on firm-wide scale economies when the really important scale issues are encountered at the level of individual businesses.

There is ample evidence, for example, that economies of scale are significant for operating economies and competitive performance in areas such as global custody,

processing of mass-market credit card transactions and institutional asset management. Economies of scale may be far less important in other areas such as private banking and M\&A advisory services. Unfortunately, empirical data on cost functions that would permit identification of economies of scale at the product level are generally proprietary, and therefore unavailable. Disturbingly, it seems reasonable that a scale-driven strategy may make a great deal of sense in specific areas of financial activity even in the absence of evidence that there is very much to be gained at the firm-wide level. Still, the notion that there are some lines of activity that clearly benefit from scale economies while at the same time observations of firm-wide economies of scale are empirically elusive, suggests that there must be numerous lines of activity (or combinations) where diseconomies of scale exist.

\section{Cost Economies of Scope}

Beyond pure scale-effects, are there cost reductions to be achieved by selling a broader rather than narrower range of products? Cost economies of scope mean that 
the joint production of two or more products or services is accomplished more cheaply than producing them separately. "Global" scope economies become evident on the cost side when the total cost of producing all products is less than producing them individually, while "activity-specific" economies consider the joint production of particular pairs or clusters of financial services. Cost economies of scope can be harvested through the sharing of IT platforms and other overheads, information and monitoring costs, and the like. Information, for example, can be reused and thereby avoid cost duplication, facilitate creativity in developing solutions to client problems, and leverage client-specific knowledge. [Stefanadis, 2002]. On the other hand, cost diseconomies of scope may arise from such factors as inertia and lack of responsiveness and creativity that may come with increased firm breadth, complexity and bureaucratization, as well as "turf" and profit-attribution conflicts that increase costs or erode product quality in meeting client needs, or serious cultural differences across the organizational "silos" that inhibit seamless delivery of a broad range of financial services.

Like economies of scale, cost-related scope economies should be directly observable in cost functions of financial services suppliers and in aggregate performance measures. Most empirical studies have failed to find significant costeconomies of scope in the banking, insurance or securities industries [Saunders 2000]. They suggest that some cost-diseconomies of scope are encountered when firms in the financial services sector add new product-ranges to their portfolios. Saunders and Walter [1994], for example, found negative cost, economies of scope among the world's 200 largest banks - as the product range widens, unit-costs seem to go up, although not dramatically so.

However, the period covered by many of these studies involve firms that were shifting away from a pure focus on banking or insurance, and may thus have incurred considerable front-end costs in expanding the range of their activities. If these outlays were expensed in accounting statements during the period under study, then one might expect to see evidence of diseconomies of scope reversed in future periods. The evidence on cost-economies of scope so far remains inconclusive. 


\section{Operating Efficiencies}

Besides economies of scale and cost-economies scope, financial firms of roughly the same size and providing roughly the same range of services can have very different cost levels per unit of output. There is ample evidence that such performance differences exist, for example, in comparisons of cost-to-income ratios among banks, insurance companies, and investment firms of comparable size. The reasons involve differences in production functions reflecting, efficiency and effectiveness in the use of labor and capital, sourcing and application of available technology, and acquisition of inputs, organizational design, compensation and incentive systems - i.e., in just plain better or worse management. These are what economists call X-efficiencies.

A number of studies have found rather large disparities in cost structures among banks of similar size, suggesting that the way banks are run is more important than their size or the selection of businesses that they pursue. [Berger, Hancock and Humphrey, 1993; Berger, Hunter and Timme, 1993] The consensus of studies conducted in the United States seems to be that average unit costs in the banking industry lie some $20 \%$

above "best practice" firms producing the same range and volume of services, with most of the difference attributable to operating economies rather than differences in the cost of funds. [Akhavein, Berger and Humphrey, 1997] Siems [1996] found that the greater the overlap in branch networks, the higher the abnormal equity returns in U.S. bank mergers, while no such abnormal returns are associated with other factors like regional concentration ratios - suggesting that shareholder value gains in many of the US banking mergers of the 1990s were associated more with increases in X-efficiency than with reductions in competition. If true, this is good news for smaller firms, since the quality of management seems to be far more important in driving costs than raw size or scope. Of course, if very large institutions are systematically better managed than smaller ones (which may be difficult to document in the real world of financial services) then there may be a link between firm size and X-efficiency.

It is also possible that very large organizations may be more capable of the massive and "lumpy" capital outlays required to install and maintain the most efficient information-technology and transactions-processing infrastructures. [Walter 2003] If 
extremely high recurring technology spend-levels results in greater X-efficiency, then large financial services firms will tend to benefit in competition with smaller ones. Smaller firms will then have to rely on pooling and outsourcing, if feasible.

In banking M\&A studies, Berger and Humphrey [1992b] found that acquiring banks tend to be significantly more efficient than the acquired banks, suggesting that the acquirer may potentially improve the X-efficiency of the target. Akhavein, Berger, and Humphrey [1997] found mega-mergers between US banks increase returns by improving efficiency rather than increasing prices, suggesting also that acquiring banks use acquisitions as an occasion to improve efficiency within their own organizations. Houston and Ryngaert [1994] and DeLong [2001b] found that the market rewards mergers where geographic overlap exists between acquirer and target, presumably due to expected X-efficiency gains.

\section{Revenue Economies of Scope}

On the revenue side, economies of scope attributable to cross-selling arise when the all-in cost to the buyer of multiple financial services from a single supplier is less than the cost of purchasing them from separate suppliers. This includes the cost of the services themselves plus information, search, monitoring, contracting and other costs. And firms that are diversified into several types of activities or several geographic areas in addition tend to have more contact points with clients. Revenue-diseconomies of scope could arise from management complexities and conflicts associated with greater breadth.

Some evidence on revenue economies of scope come from historical studies. Kroszner and Rajan [1994] found that U.S. bank affiliates typically underwrote better performing securities than specialized investment banks during the 1920s, when US commercial banks were permitted to have securities affiliates. Perhaps commercial banks obtained knowledge about firms contemplating selling securities through the deposit and borrowing history of the firm. If so, they could then select the best risks to bring to market. Likewise, Puri [1996] found that securities underwritten by commercial banks generated higher prices than similar securities underwritten by investment banks; 
this suggests lower ex ante risk for those underwritten by commercial banks.

Most empirical studies of cross-selling are based on survey data, and are therefore difficult to generalize. Regarding wholesale commercial and investment banking services, for example, Exhibit 3 shows the results of a 2001 survey of corporate clients by Greenwich Research regarding the importance of revenue economies of scope between lending and M\&A advisory services. The issue is whether companies are more likely to award M\&A work to banks that are also willing lenders, or whether the two services are separable - so that companies go to the firms with the perceived best M\&A capabilities (probably investment banking houses) for advice and to others (presumably the major commercial banks) for loans. The responses suggests that companies view these services as a single value-chain, so that banks that are willing to provide significant lending are also more likely to obtain M\&A advisory work. Indeed, Exhibit 4 suggests that well over half of the major M\&A firms (in terms of fees) in 2001 were commercial banks with substantial lending power. This is sometimes called "mixed bundling," meaning that the price of one service (e.g., commercial lending) is dependent on the client also taking another service (e.g., M\&A advice or securities underwriting), although the search for immediate scope-driven revenue gains may have led to some disastrous lending by commercial banks in the energy and telecoms sectors in recent years.

However, it is at the retail level that the bulk of the revenue economies of scope are likely to materialize, since the search costs and contracting costs of retail customers are likely to be higher than for corporate customers. There is limited US evidence on retail cross-selling due to the regulatory restraints in place until 1999, and evidence from Europe, where universal banking and multifunctional financial conglomerates have always been part of the landscape, is mainly case-based and suggests highly variable outcomes as to the efficacy of bancassurance or Allfinanz.

In any case, the future may see some very different retail business models. One example is depicted in Exhibit 5. Here clients take advantage of user-friendly home interfaces to access Webservice platforms which allow real-time linkages to multiple financial services vendors. For the client, it could combine the "feel" of single-source 
purchasing with access to best-in-class vendors - the client "cross-purchases" rather than being "cross-sold." Absent the need for continuous financial advice, such a business model could reduce information costs, transactions costs and contracting costs while at the same time providing client-driven open-architecture access to the universe of competing vendors. Advice could be built into the model by suppliers who find a way to incorporate the advisory function into their downlinks, or through independent financial advisers. If in the future such models of retail financial services delivery take hold in the market, then some of the rationale for cross-selling and revenue economies of scope could become obsolete.

Despite an almost total lack of hard empirical evidence, revenue economies of scope may indeed exist at both the wholesale and retail level. But they are likely to be very specific to the types of services provided and the types of clients served. So revenue-related scope economies are clearly linked to a firm's specific strategic positioning across clients, products and geographies depicted in Exhibit 2. Even if cross-selling potential exists, the devil is in the details - mainly in the design of incentives and organizational structures to ensure that it actually occurs. And these incentives have to be extremely granular and compatible with employee real-world behavior. Without them, no amount of management pressure and exhortation to crosssell is likely to achieve its objectives.

Network economies associated with multifunctional financial firms may be considered a special type of demand-side economy of scope. [Economides, 1995] Like telecom-munications, relationships with end-users of financial services represent a network structure wherein additional client linkages add value to existing clients by increasing the feasibility or reducing the cost of accessing them. So-called "network externalities" tend to increase with the absolute size of the network itself. Every client link to the firm potentially "complements" every other one and potentially adds value through either one-way or two-way exchanges. The size of network benefits depends on technical compatibility and coordination in time and location, which universal banks and financial conglomerates may be in a position to provide. And networks tend to be selfreinforcing in that they require a minimum critical mass and tend to grow in dominance 
as they increase in size, thus precluding perfect competition in network-driven businesses. This characteristic may be evident in activities such as securities clearance and settlement, global custody, funds transfer and international cash management, and may to lock-in clients insofar as switching-costs tend to be relatively high.

What little empirical evidence there is suggests that revenue-economies of scope seem to exist for specific combinations of products in the realm of commercial and investment banking, as well as insurance and asset management. Empirical evidence concerning the existence of certain product-specific revenue economies of scope is beginning to materialize. For example, Yu [2001] showed that share prices of US financial conglomerates as well as specialists responded favorably when the Financial Services Modernization Act of 1999 was announced. The study found that the market reacted most favorably for the shares of large securities firms, large insurance companies, and bank holding companies already engaged in some securities businesses (those with Section 20 subsidiaries allowing limited investment banking activities). The study suggested that the market expected gains from product diversification possibly arising from cross-product synergies. Another study by Lown et al. (2000) similarly found that both commercial and investment bank stocks rose on announcement by President Clinton on October 22, 1999 that passage of the Gramm Leach Bliley Act was imminent.

\section{Market Power}

In addition to the strategic search for operating economies and revenue synergies, financial services firms will also seek to dominate markets in order to extract economic returns. This often referred to as economies of "size" as opposed to classic economies of "scale," and can convey distinct competitive advantages that are reflected in either business volume or margins, or both.

Market power allows banks to charge more (monopoly benefits) or pay less (monopsony benefits). Indeed, many national markets for financial services have shown a distinct tendency towards oligopoly. Supporters argue that high levels of market concentration are necessary in order to provide a viable competitive platform. Without 
convincing evidence of scale economies or other size-related efficiency gains, opponents argue that monopolistic market structures serve mainly to extract rents from consumers or users of financial services and redistribute them to shareholders, crosssubsidize other areas of activity, invest in wasteful projects, or reduce pressures for cost-containment.

Indeed, it is a puzzle why managers of financial services firms often seem to believe that the end-game in their industry's competitive structure is the emergence of a few firms in gentlemanly competition with nice sustainable margins, whereas in the real world such an outcome can easily trigger public policy reaction leading to breaks-ups and spin-offs in order to restore more vigorous competition. Particularly in a critical economic sector that is easily politicized such as financial services, a regulatory response to "excessive" concentration is a virtual certainty despite sometimes furious lobbying to the contrary. In the case of Canada, for example, regulators prevented two megamergers in late 1998 that would have reduced the number of major financial firms from five to three with a retail market share of perhaps $90 \%$ between them. Regulators blocked the deals despite arguments by management that major US financial services firms operating in Canada under the rules of the North American Free Trade Agreement (NAFTA) would provide the necessary competitive pressure to prevent exploitation of monopoly power.

Financial services market structures differ substantially as measured, for example, by the Herfindahl-Hirshman index. This metric of competitive structure is the sum of the squared market shares $\left(\mathrm{H}=\Sigma \mathrm{s}^{2}\right)$, where $0<\mathrm{H}<10,000$ and market shares are measured for example, by deposits, by assets, or other indicators of market share. $\mathrm{H}$ rises as the number of competitor declines, and as market-share concentration increases among a given number of competitors. Empirically, higher values of $\mathrm{H}$ tend to be associated with higher degrees of pricing power, price-cost margins, and returns on equity across a broad range of industries. For example, despite very substantial consolidation in recent years within perhaps the most concentrated segment of the financial services industry, wholesale banking and capital markets activities, there is little evidence of market power. With some $80 \%$ of the combined value of global fixed- 
income and equity underwriting, loan syndications and M\&A mandates captured by the top-ten firms, the Herfindahl-Hirshman index was still only 745 in 2001. This suggests a ruthlessly competitive market structure in most of these businesses, which is reflected in the returns to investors who own shares in the principal players in the industry - in fact, there has been a long-term erosion of return on capital invested in the wholesale banking industry. [Smith and Walter, 2003]

Another example is asset management, where the top firms comprise a mixture of European, American and Japanese asset managers and at the same time a mixture of banks, broker-dealers, independent fund management companies and insurance companies. Although market definitions clearly have to be drawn more precisely, at least on a global level asset management seems to be among the most contestable in the entire financial services industry, with a Herfindahl-Hirshman index of 540 among the top- 40 firms in terms of assets under management. And it shows very few signs of increasing concentration in recent years.

In short, although monopoly power created through mergers and acquisitions in the financial services industry can produce market conditions that allow firms to reallocate gains from clients to themselves, such conditions are not easy to achieve or to sustain. Sometimes new players - even relatively small entrants - penetrate the market and destroy oligopolistic pricing structures. Or there are good substitutes available from other types of financial services firms and consumers are willing to shop around. Vigorous competition (and low Herfindahl-Hirshman indexes) seems to be maintained even after intensive M\&A activity in most cases as a consequence of relatively even distributions of market shares among the leading firms in many financial services businesses.

Berger and Hannan [1996] found that loan rates were higher and deposit rates were lower when banks operated in concentrated markets. These increased revenues, however, did not result in higher profits - instead, the study showed evidence consistent with higher cost structures in such banks than their counterparts in less concentrated markets. Akhavein, Berger, and Humphrey [1997] found that banks which merge charge more for loans and pay less on deposits before they merge than other large 
banks -- banks that merged charged 17 basis points more for loans than the average large bank prior to merging. After the merger, however, this difference fell to about 10 basis points. This suggests that merging banks do not tend to take advantage of their increased market power. The authors contend that antitrust policy is effective in preventing mergers that would create market power problems. Siems [1996] reached a similar conclusion. In a study of 19 bank megamergers (partners valued over $\$ 500$ million) in 1995, he rejected the market power hypothesis although he found that inmarket mergers create positive value for both the acquirer and the target upon announcement. There was no relationship between the resulting abnormal returns and the change in the Herfindahl-Hirshman index. Still, concentration seems to affect prices. Beatty, Santomero, and Smirlock [1987] found that the higher the market concentration of the banking industry in a given region, the higher the premium paid to acquire a bank in that area.

\section{Proprietary Information and Imbedded Human Capital}

One argument in favor of large, diverse financial services industry is that internal information flows are substantially better and involve lower costs than external information flows in the market that are accessible by more narrowly focused firms. Consequently a firm that is present in a broad range of financial markets, functions and geographies can find proprietary and client-driven trading and structuring opportunities that smaller and more narrow firms cannot.

A second argument has to do with technical know-how. Significant areas of financial services - particularly wholesale banking and asset management - have become the realm of highly specialized expertise which can be reflected in both market share and price-effects. In recent years, large numbers of financial boutiques have been acquired by major banks, insurance companies, securities firms and asset managers for precisely this purpose, and anecdotal evidence suggests that in many cases these acquisitions have been shareholder-value enhancing for the buyer.

Closely aligned is the human capital argument. Technical skills and entrepreneurial behavior are embodied in people, and people can and do move. Parts 
of the financial services industry have become notorious for the mobility of talent to the point of "free-agency," and people or teams of people sometimes regard themselves as "firms within firms." There are no empirical studies of these issues, although there is no question about their importance. Many financial services represent specialist businesses that are conducted by specialists meeting specialist client requirements. Knowhow embodied in people is clearly mobile, and the key is to provide a platform that is sufficiently incentive compatible to make the most of it. It seems unclear whether size or breadth has much to do with this.

\section{Diversification of Business Streams, Credit Quality and Financial Stability}

Greater diversification of earnings attributable to multiple products, client-groups and geographies is often deemed to create more stable, safer, and ultimately more valuable financial institutions. The lower the correlations among the cash flows from the firm's various activities, the greater the benefits of diversification. The consequences should include higher credit quality and higher debt ratings (lower bankruptcy risk), therefore lower costs of financing than those faced by narrower, more focused firms, while greater earnings stability should bolster stock prices. In combination, these effects should reduce the cost of capital and enhance profitability.

It has also been argued that shares of universal banks and financial conglomerates embody substantial franchise value due to their conglomerate nature and importance in national economies. Demsetz, Saidenberg and Strahan [1996] suggest this guaranteed franchise value serves to inhibit extraordinary risk-taking. They find substantial evidence that the higher a bank's franchise value, the more prudent management tends to be. Such firms should therefore serve shareholder interests, as well as stability of the financial system - and the concerns of its regulators - with a strong focus on risk management, as opposed to financial firms with little to lose. This conclusion is, however, at variance with the observed, massive losses incurred by financial conglomerates universal banks in recent years in credit exposures to highly leveraged firms and special-purpose entities, real estate lending and emerging market transactions. 
Studies that test risk reduction often look at how hypothetical combinations could have reduced risk using actual industry data. In an early study, Santomero and Chung [1992] found that bank holding companies which existed from 1985 to 1989 could have reduced their probability of failure had they been permitted to diversify into insurance and securities. Of the ten combinations the authors examined, the best combination is the bank holding company linking to both insurance and securities firms. The only combination that would have increased the probability of bankruptcy over a stand-alone bank holding company is one encompassing a large securities firm. Boyd, Graham, and Hewitt [1993] tested whether hypothetical mergers between bank holding companies and non-banking financial firms decrease risk. In their sample of data from 1971 to 1987, they found that mergers between bank holding companies and insurance firms could have reduced risk while mergers between bank holding companies and securities firms or real estate firms could have increased risk. Saunders and Walter [1994] carried out a series of simulated mergers between US banks, securities firms and insurance companies in order to test the stability of earnings of the pro-forma "merged" firm as opposed to separate institutions. The opportunity-set of potential mergers between existing firms and the risk-characteristics of each possible combination were examined. The findings suggest that there are indeed potential risk-reduction gains from diversification in multi-activity financial services organizations, and that these increase with the number of activities undertaken. The main risk-reduction gains appear to arise from combining commercial banking with insurance activities, rather than with securities activities.

\section{Too Big to Fail Guarantees}

Given the unacceptable systemic consequences of institutional collapse, large financial services firms that surpass a given threshold will be bailed-out by taxpayers. In the United States, this policy became explicit in 1984 when the Comptroller of the Currency testified to Congress that 11 banks were so important that they would not be permitted to fail. [O'Hara and Shaw, 1990] It was clearly present in the savings and loan collapses around that time. In other countries the same policy tends to exist, and seems 
to cover even more of the local financial system. [US General Accounting Office, 1991] There were numerous examples in France, Switzerland, Norway, Sweden, Finland, and Japan during the1990s. Implicit too-big-to-fail (TBTF) guarantees create a potentially important public subsidy for major financial firms.

TBTF support was arguably extended to non-bank financial firms in the rescue of Long-term Capital Management, Inc. in 1998, brokered by the Federal Reserve (despite the fact that a credible private restructuring offer was on the table) on the basis that the firm's failure could cause systemic damage to the global financial system. The same argument was made by JP Morgan in 1996 about the global copper market and one of its then-dominant traders, Sumitomo. Morgan suggested that collapse of the copper market could have serious systemic effects. The speed with which the central banks and regulatory authorities reacted to that crisis signaled the possibility of safety-net support of the copper market in light of major banks' massive exposures in highly complex structured credits to the industry. And there were even mutterings of systemic effects in the collapse of Enron in 2001. Most of the time such arguments are selfserving nonsense, but in a political environment under crisis conditions they could help throw a safety net sufficiently broad to limit damage to shareholders of exposed banks or other financial firms.

It is generally accepted that the larger the bank, the more likely it is to be covered under TBTF support. O'Hara and Shaw [1990] detailed the benefits of TBTF status: Without state assurances, uninsured depositors and other liability holders demand a risk premium. When a bank is not permitted to fail, the risk premium is no longer necessary. Furthermore, banks covered under the policy have an incentive to increase their risk in order to enjoy higher equity returns. Kane [2000] investigated the possibility that large banks enjoy access to the TBTF guarantees in a study of merger-effects, although he did not distinguish between the stock market reaction to increased TBTF guarantees or the likelihood of increased profitability. He suggested further study to determine whether acquiring banks increase their leverage, uninsured liabilities, non-performing loans and other risk exposures, all of which would suggest that they are taking advantage of TBTF guarantees. 
One problem with the TBTF argument is to determine precisely when a financial institution becomes too big to fail. Citicorp was already the largest bank holding company in the United States before it merged with Travelers in 1998. Therefore, the TBTF argument may be a matter of degree. That is, the benefits of becoming larger may be marginal if a firm already enjoys TBTF status.

\section{Conflicts of Interest}

The potential for conflicts of interest is endemic in all multifunctional financial services firms. [Saunders and Walter,1994] Classic conflict of interest arguments include the following: (1) When firms have the power to sell affiliates' products, managers may no longer dispense "dispassionate" advice to clients and have a salesman's stake in pushing "house" products, possibly to the disadvantage of the customer; (2) A financial firm that is acting as an underwriter and is unable to place the securities in a public offering may seek limit losses by "stuffing" unwanted securities into accounts over which it has discretionary authority; (3) A bank with a loan outstanding to a client whose bankruptcy risk has increased, to the private knowledge of the banker, may have an incentive to encourage the borrower to issue bonds or equities to the general public, with the proceeds used to pay-down the bank loan; ${ }^{2}(4)$ In order to ensure that an underwriting goes well, a bank may make below-market loans to thirdparty investors on condition that the proceeds are used to purchase securities underwritten by its securities unit; (5) A bank may use its lending power activities to encourage a client to also use its securities or securities services; and (6) By acting as a lender, a bank may become privy to certain material inside information about a customer or its rivals that can be used in setting prices, advising acquirers in a contested acquisition or helping in the distribution of securities offerings underwritten by its securities unit. [Smith and Walter, 1997A] More generally, a financial firm may use proprietary information regarding a client for internal management purposes which at

\footnotetext{
${ }^{2}$ One example is the 1995 underwriting of a secondary equity issue of the Hafnia Insurance Group by Den Danske Bank. The stock was distributed heavily to retail investors, with proceeds allegedly used to pay-down bank loans even as Hafnia slid into bankruptcy [Smith and Walter, 1997B] The case came before the Danish courts in a successful individual investor litigation supported by the government
} 
the same time harms the interests of the client.

The potential for conflicts of interest can be depicted in a matrix such as Exhibit 6 . Many of the cells in the matrix represent various degrees and intensities of interestconflicts. Some are serious and basically intractable. Others can be managed by appropriate changes in incentives or compliance initiatives. And some are not sufficiently serious to worry about. But using a matrix approach to mapping conflicts of interest demonstrates that the broader the client and product range, the more numerous are the potential conflicts and interest and the more difficult the task of keeping them under control -- and avoiding possibly large franchise losses.

Shareholders of financial firms have a vital stake in the management and control of conflicts of interest. They can benefit from conflict-exploitation in the short term, to the extent that business volumes and/or margins are higher as a result. And preventing conflicts of interest is an expensive business -- compliance systems are costly to maintain, and various types of walls between business units can have high opportunity costs because of inefficient use of information within the organization. On the other hand, costs associated with civil or criminal action and reputation losses due to conflicts of interest can weigh on shareholders very heavily indeed, as demonstrated by a variety of such problems in the financial services industry during 2000-2002. Some have argued that conflicts of interest may contribute to the price to book-value ratios of the shares of financial conglomerates and universal banks falling below those of more specialized financial services businesses.

Conflicts of interest can also impede market performance. For example, inside information accessible to a bank as lender to a target firm would almost certainly prevent that bank from acting as an M\&A adviser to a potential acquirer. Entrepreneurs may not want their private banking affairs handled by a bank that also controls their business financing. A mutual fund investor is unlikely to have easy access to the full menu of available equity funds though a financial conglomerate offering competing inhouse products. These issues may be manageable if most of the competition is coming from other financial conglomerates. But if the playing field is also populated by aggressive insurance companies, independent broker-dealers, fund managers and 
other specialists, these issues tend to be a continuing strategic challenge for management (and a source of comfort for clients).

Should a major conflict of interest arise, the repercussions for a firm's reputation can be quite detrimental. ${ }^{3}$ Recent well-reported examples include equity analyst conflicts of interest in the late 1990s and early 2000s. Analysts working for multifunctional financial firms wear several hats and are subject to multiple conflicts of interest. They are supposed to provide unbiased research to investors. But they are also expected to take part in the securities origination and sales process centered in their firms' corporate finance departments. The firms argue that expensive research functions cannot be paid-for by attracting investor deal-flow and brokerage commissions, so that corporate finance has to cover much of the cost. This fact, and the astronomical compensation packages commanded by top analysts (occasionally exceeding $\$ 20$ million per year) is the best demonstration of which of the two hats dominates. Prosecution of Merrill Lynch by the Attorney General of the State of New York in 2002, a $\$ 100$ million settlement, and a frantic scramble by all securities firms to reorganize how equity research is organized and compensated simply validated facts long known to market participants.

More broadly, both Citigroup and JP Morgan Chase in 2001 and 2002 were touched by just about every US corporate scandal that was revealed, often involving conflicts of interest, and both lost well over a third of their equity value in a matter of months (see Exhibit 7) no doubt in part as a consequence of conflicts of interest.

\section{Conglomerate Discount}

It is often argued that the shares of multi-product firms and business conglomerates tend to trade at prices lower than shares of more narrowly-focused firms (all else equal). There are two basic reasons why this "conglomerate discount" is

\footnotetext{
${ }^{3}$ For example, J.P. Morgan simultaneously served as commercial banker, investment banker, and adviser to Banco Español de Crédito (Banesto) in Spain, as well as being an equity holder and fund manager for co-investors in a limited partnership holding shares in the firm. Additionally, Morgan's Vice Chairman served on Banesto's Supervisory Board. When Banesto failed and the conflicts of interest facing JP Morgan were revealed, the value of the firm's equity fell by $10 \%$ - see Smith and Walter [1997].
} 
alleged to exist.

First, it is argued that, on the whole, conglomerates tend to use capital inefficiently. It is argued that the potential benefits of diversification against the potential costs that include greater management discretion to engage in value-reducing projects, cross-subsidization of marginal or loss-making projects that drain resources from healthy businesses, misalignments in incentives between central and divisional managers, and the like. For a sample of U.S. corporations during the period 1986-91, Berger and Ofek [1995] demonstrated an average value-loss in multi-product firms on the order of $13-15 \%$, as compared to the stand-alone values of the constituent businesses. The bulk of value-erosion in conglomerates was attributed by the authors to over-investment in marginally profitable activities and cross-subsidization. This valueloss was smaller in cases where the multi-product firms were active in closely-allied activities within the same industrial sector. In other empirical work, John and Ofek [1995] showed that asset sales by corporations result in significantly improved shareholder returns on the remaining capital employed, both as a result of greater focus in the enterprise and value-gains through high prices paid by asset buyers. The evidence suggests that the internal capital market within conglomerates functions less efficiently than the external capital market.

Such empirical findings across broad ranges of industry may well apply to diverse activities carried out by financial firms as well. If retail banking and wholesale banking and $\mathrm{P} \& \mathrm{C}$ insurance are evolving into highly-specialized, performance-driven businesses, for example, one may ask whether the kinds of conglomerate discounts found in industrial firms may not also apply to financial conglomerate structures -especially if centralized decision-making is becoming increasingly irrelevant to the requirements of the specific businesses.

A second possible source of a possible conglomerate discount is that investors in shares of conglomerates find it difficult to "take a view" and add pure sectoral exposures to their portfolios. Investors may want to avoid such stocks in their efforts to construct 
efficient asset-allocation profiles. This is especially true of performance-driven managers of institutional equity portfolios who are under pressure to outperform cohorts or equity indexes. Why would a fund manager want to invest in yet another (closed-end) fund in the form of a conglomerate - one that may be active in retail banking, wholesale commercial banking, middle-market lending private banking, corporate finance, trading, investment banking, asset management insurance and perhaps other businesses as well?

Both the capital-misallocation effect and the portfolio-selection effect may weaken investor demand for shares of universal banks and financial conglomerates, lower their equity prices, and produce a higher cost of capital than if the conglomerate discount were absent. This higher cost of capital would have a bearing on the competitive performance and profitability of the enterprise. It may wholly or partially offset some of the aforementioned benefits of conglomeration, such as greater stability and lower bankruptcy risk through diversification across business lines.

\section{From Book Value of Equity to Market Value of Equity}

From a shareholder perspective, all of the pluses and minuses of size and breadth among financial services firms can be captured in a simple valuation formula:

$$
N P V_{f}=\sum_{t=0}^{n} \frac{E\left(R_{t}\right)-E\left(C_{t}\right)}{\left(1+i_{t}+\alpha_{t}\right)^{t}}
$$

$\mathrm{NPV}_{\mathrm{f}}$ denotes the risk-adjusted discounted present value of a firm's after-tax earnings, $E\left(R_{t}\right)$ a represents the expected future revenues of the firm, $E\left(C_{t}\right)$ represents expected future operating costs including charges to earnings for restructurings, loss provisions and taxes. The net expected returns in the numerator are then discounted to the present using a risk-free rate $\mathrm{i}_{\mathrm{t}}$ and a composite risk adjustment $\alpha_{\mathrm{t}}$-- which captures the variance of expected net future returns resulting from credit risk, market risk, operational risk, and reputation risk, and at the same time captures the correlations between such risks associated with the firm's various activities.

Strategic initiatives in financial firms increase shareholder value if they generate: (1) Top-line gains which show up as increases in $E\left(R_{t}\right)$ due for example to market- 
extension, increased market share, wider profit margins or successful cross-selling; (2) Bottom-line gains related to lower costs due to economies of scale or improved operating efficiency, -- reduced $E\left(C_{t}\right)$-- usually reflected in improved cost-to-income ratios, as well as better tax efficiency; or (3) Reductions in risk associated with improved risk management or diversification of the firm across business streams, client segments or geographies whose revenue contributions are imperfectly correlated and therefore reduce the composite $\alpha_{t}$.

This relationship can be depicted in a different way in Exhibit 8. The left-hand bar represents the adjusted book value of equity (ABVE). This starts with the book value of equity (BVE) - the sum of: (1) The par value of shares when originally issued; (2) The surplus paid-in by investors when the shares were issued; (3) Retained earnings on the books of the bank; and (4) Reserves set aside for loan losses. [Saunders, 2000] BVE must be written-up or written-down by unrealized capital gains or losses associated with the mark-to-market values of all balance sheet items. This calculation yields the adjusted book value of equity (ABVE). Its value may depart significantly from BVE for banks and insurance companies due to a general absence of market-value accounting across major categories of balance sheet items, although it may come pretty close for securities firms and asset managers.

After all balance sheet values have been taken into account and marked to market there may still be a material difference between ABVE and the actual market value of equity (MVE). This difference represents the market's assessment of the present value of the risk-adjusted future net earnings stream, capturing all known or suspected business opportunities, costs and risks facing the firm and captured in the above equation - the "franchise value" of the firm.

A simpler version is "Tobin's Q," defined as the ratio of the market value of a firm's equity divided by a firm's book value. If the $Q$ ratio is significantly below 1 , for example, it may be that breaking-up the firm can serve the interests of shareholders if the book value of equity can be monetized. The $Q$ ratio for well-run financial firms having a positive franchise value should normally be well in excess of 1 , and is clearly susceptible to enhancement through managerial action. 
In Exhibit 8, each of the factors related to the size and breadth of financial services firms is identified in successive bars in the diagram - scale and scope effects, operating and tax efficiencies, stability and TBTF premiums, conglomerate discount, and the rest - in building to the value of equity observed in the market, MVE. The difference between book value or market-adjusted book value could be highly positive, as it has been in the case of AIG in the insurance sector, for example. Or it could be significantly negative, with the firm's stock trading well below book value or even notional market-adjusted book value (its presumptive liquidation value). For example, in late September 2002 JP Morgan Chase stock was trading below book value, reflecting concerns of large exposures (especially in the telecoms sector) and questions about the bank's strategy and its execution. ${ }^{4}$

When strategic initiatives are undertaken, such as mergers or acquisitions, it is possible to add some empirical content to this kind of construct. In terms of US completed deals during a period of intense M\&A activity in the 1980s and early 1990s, commercial bank acquisitions occurred at price-to-book value ratios of about 2.0, sometimes as high as 3.0 or even more. In eight of the eleven years covered by one study [Smith and Walter, 2000], the mean price-to-book ratio for US commercial banking acquisitions was below 2.0, averaging 1.5 and ranging from 1.1 in 1990 to 1.8 in 1985. In two years, the price-to-book ratio exceeded 2.0 - in 1986 it was 2.8 and in 1993 in was 3.2. These values presumably reflect the opportunity for the acquired institutions to be managed differently and to realize the incremental value needed to reimburse the shareholders of the acquiring institutions for the willingness to pay the premium in the first place. If in fact the potential to capture value for multifunctional financial firms exceeds that for the traditional US-type separated commercial banks reflected in such studies, this should be reflected in higher merger premiums outside the United States as well as within the US after the 1999 liberalization of line-of-business restrictions.

\footnotetext{
4 “Strategy Worries Hit JP Morgan Share Price," Financial Times, 19 September 2002.
} 
Event study methodology [Brown and Warner, 1985] can also be used to determine investor reaction to events such as the announcement of a presumably value-enhancing merger that adds either size or scope. The technique controls for conditions in the general market and tries determine the relationship that a particular stock has with the market under "normal" conditions -- that is, before the event occurs. This relationship can be established by regressing the returns of the stock on the market index and a constant. ${ }^{5}$ One then determines what the stock "should" have earned (total return) given the state of the general market as well as the stock's past relationship with that market. These hypothetical returns are compared with actual returns to determine the abnormal returns -- that is, how much more or less the stock actually earns as a result of the announcement. ${ }^{6}$

Abnormal returns are added together over various time periods, usually several days before the announcement to several days after. One needs to look at a few days before the event in case any news about the event has leaked and affected the value of the stock. Looking at the abnormal returns for a few days after the announcement allows one to take "second thoughts" into account. The market may be so surprised by an announcement that the market may need a few days to digest the news. One cannot know for sure the ideal length of the pre- or post-event periods. Extending either period leads to problems, since other events such as earnings reports or changes in management could have occurred and the market could be reacting to them instead of the one being examined.

\footnotetext{
${ }^{5}$ We obtain the following relationship: $a_{i}+b_{i} R_{M t}$, where $R_{M t}=$ the return on the market at time $t ; \alpha_{i}=$ egression result on the constant; $\beta_{\mathrm{i}}=$ relationship between the market and stock $i$, also known as the beta of stock $i$.

${ }^{6}$ That is, $A R_{i t}=R_{i t}-\left(\alpha_{i}+\beta_{i} R_{M t}\right)$, where $A R_{i t}=$ abnormal return for stock $i$ at time $t ; R_{i t}=$ return on stock $i$ at time $t$; and $\mathrm{R}_{\mathrm{Mt}}=$ the return on the market at time $t$.
} 
As an example of how the event study approach can be used, we applied it to the seven strategic M\&A deals undertaken by UBS AG and its predecessor organizations during the period 1992-2000. These include the Swiss Bank Corporation acquisition of O'Connor (9 January 1992), the SBC acquisition of Brinson (31 August 1994), the SBC acquisition of S.G. Warburg (2 May 1995), the SBC takeover of Dillon Read (15 May 1997), the merger of Swiss Bank Corporation and Union Bank of Switzerland to form the present UBS AG (8 December 1997), the UBS acquisition of Global Asset Management (GAM) announced in 13 September 1999, and the UBS acquisition of PaineWebber announced on 11 July 2000. The first four deals were undertaken by Swiss Bank Corporation, and can therefore be viewed in terms of SBC share price impacts, the SBC-UBS merger in 1997 can be examined in terms of both SBC and UBS cumulative abnormal returns, while the GAM and PaineWebber deals would have affected the shares of the new UBS AG.

We estimated alpha and beta using daily returns from 500 to 10 days before the merger announcement by regressing the returns of the stock on the returns of the Swiss SMI index. To determine the extent to which a particular merger was perceived by the market to have created or destroyed value, we cumulated the abnormal returns for various event windows for each SBC and UBS transaction beginning with O'Connor in 1992 and ending with PaineWebber in 2000. As mentioned above, no scientific way of determining the ideal event window exists. No confounding events (earnings reports, changes in management, other major mergers) occurred around the time of the merger announcements. We therefore conclude that the market was reacting only to the announcement of the particular merger. The respective calculated abnormal returns are as follows: 


\begin{tabular}{|l|c|c|c|c|c|}
\hline & & \multicolumn{3}{|c|}{ Abnormal Returns for Acquiror } \\
\hline Merger & Date & Event Date & {$[-1,+1]$ window } & {$[-3,+3]$ window } & {$[-5,+5]$ window } \\
\hline SBC O'Connor & 9-Jan-92 & $0.444 \%$ & $0.930 \%$ & $-2.587 \%$ & $0.902 \%$ \\
\hline SBC Brinson & $31-$ Aug-94 & $-0.713 \%$ & $1.084 \%$ & $-3.704 \%$ & $-5.205 \%$ \\
\hline SBC Warburg & 2-May-95 & $-0.012 \%$ & $-2.515 \%$ & $-5.170 \%$ & $-7.127 \%$ \\
\hline SBC Dillon Read & $15-M a y-97$ & $-0.413 \%$ & $-1.551 \%$ & $-1.842 \%$ & $5.231 \%$ \\
\hline SBC-UBS (for SBC) & $8-D e c-97$ & $4.108 \%$ & $7.756 \%$ & $5.929 \%$ & $4.936 \%$ \\
\hline SBC-UBS (for UBS) & $8-D e c-97$ & $9.368 \%$ & $13.133 \%$ & $12.813 \%$ & $10.256 \%$ \\
\hline UBS-GAM & $13-S e p-99$ & $-0.082 \%$ & $0.977 \%$ & $1.452 \%$ & $-0.899 \%$ \\
\hline UBS-PaineWebber & $11-J u l-00$ & $-0.244 \%$ & $-7.306 \%$ & $-2.795 \%$ & $-3.509 \%$ \\
\hline
\end{tabular}

No regularity is obvious from the market's reactions to SBC or UBS merger or acquisition announcements based on the seven cases examined here. That is, the market appears to judge each merger on its own merits. Market reaction to the merger of UBS and SBC, for example, was highly positive for shareholders of both firms, possibly reflecting costs cuts (especially in the domestic banking business) that could be made possible by the merger together with the presumably stronger competitive position of the new UBS AG in its various lines of activity, notably private banking and investment banking. This in line with earlier event study research such as DeLong [2001b] and Houston, James and Ryngaert [1999] who find that in-market (focusing) mergers tend to create value upon announcement based on the US financial services deal-flow -- targets of in-market mergers gain and acquirers do not lose. On the other hand, market reaction to the UBS acquisition of PaineWebber was strongly negative, probably in large part due to the high price paid.

\section{Conclusions}

Assessing the potential effects of size and scope in financial services firms is as straightforward in concept as it is difficult to calibrate in practice. The positives include economies of scale, improvements in operating efficiency (including the impact of technology), cost economies of scope, revenue economies of scope, impact on market structure and pricing power, improved financial stability through diversification of revenue streams, improvements in the attraction and retention of human capital, and possibly TBTF support. The negatives include diseconomies of scale, higher operating costs due to increased size and complexity, diseconomies of scope on either the cost or 
revenue sides (or both), the impact of possible conflicts of interest on the franchise value of the firm, and a possible conglomerate discount in the share price. Bigger and broader is sometimes better, sometimes not. It all depends.

The evidence so far suggests rather limited prospects for firm-wide cost economies of scale and scope among major financial services firms in terms of overall cost structures, although they certainly exist in specific lines of activity. Operating economies (X-efficiency) seems to be the principal determinant of observed differences in cost levels among banks and nonbank financial institutions. Revenue-economies of scope through cross-selling may well exist, but they are likely to apply very differently to specific client segments and product lines. Conflicts of interest can pose major risks for shareholders of multifunctional financial firms, which may materialize in civil or even criminal litigation and losses in franchise value, There is plenty of evidence that diversification across uncorrelated business streams promotes stability, although unexpected correlation spikes (as between insurance and investment banking) may arise from time to time.

Exhibit 9 shows the most valuable financial services in the North America and Europe in terms of market capitalization. Two observations could be made. First, the largest by whatever measures are used in the major industry segments are not necessarily the most valuable. Indeed, rank correlations between size and market value are low. And second, both lists are highly diverse. Generalists and specialists cohabitate at the top of the financial services league tables in both regions of the world. Both observations suggest that the key is in "how" things are done rather than "what" is done. While the burden of proof tends fall on bigger and broader firms, a few cases like GE Capital Services (a conglomerate within a conglomerate) shows that specialist businesses run by specialists on a highly-rated capital platform -- subject to unrelenting pressure to sweat the equity by a demanding corporate owner insisting on market dominance together with benchmark attention of service quality, cost control and risk control, shows that it can be done and that it can be done on a sustained basis. Although even here the issue of transparency eventually forced a breakup of GE Capital's organizational structure in 2002. 
In a way, the absence of clear signs of "strategic dominance" - generalists gaining the upper hand over specialists or the other way round - is encouraging. Any number can play, and there are no magic formulas. The devil remains in the details, and there is a premium on plain old good management. From a systemic perspective as well, diversity in the financial system is probably a good thing, as firms competing across strategic groups as well as within them put a premium on both efficiency in financial allocation and innovation in the evolution of financial products and processes. 
Exhibit 1

Multifunctional Financial Linkages

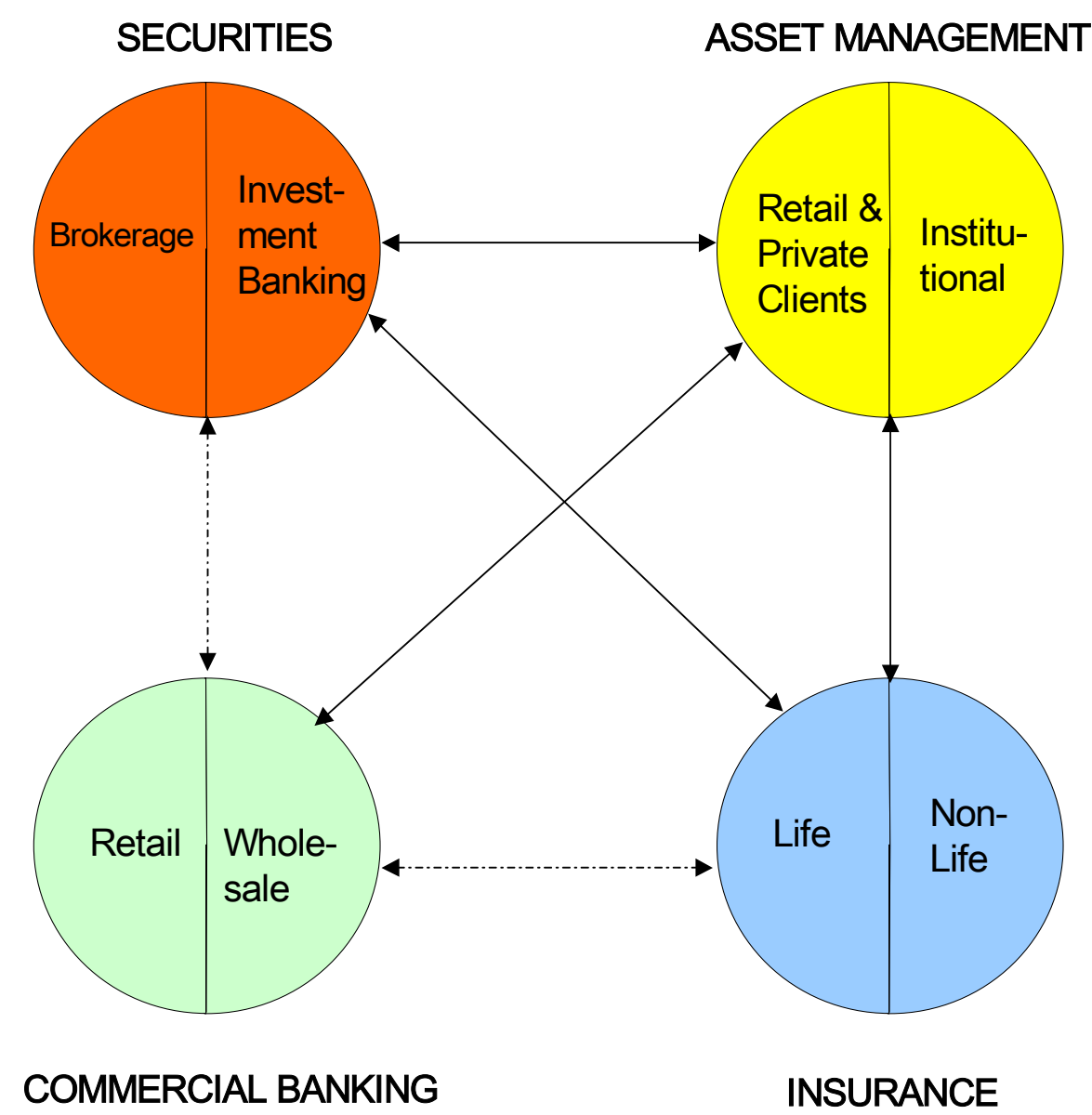




\section{Exhibit 2}

Product-Specific. Client-Specific and Geographic Strategic Linkages

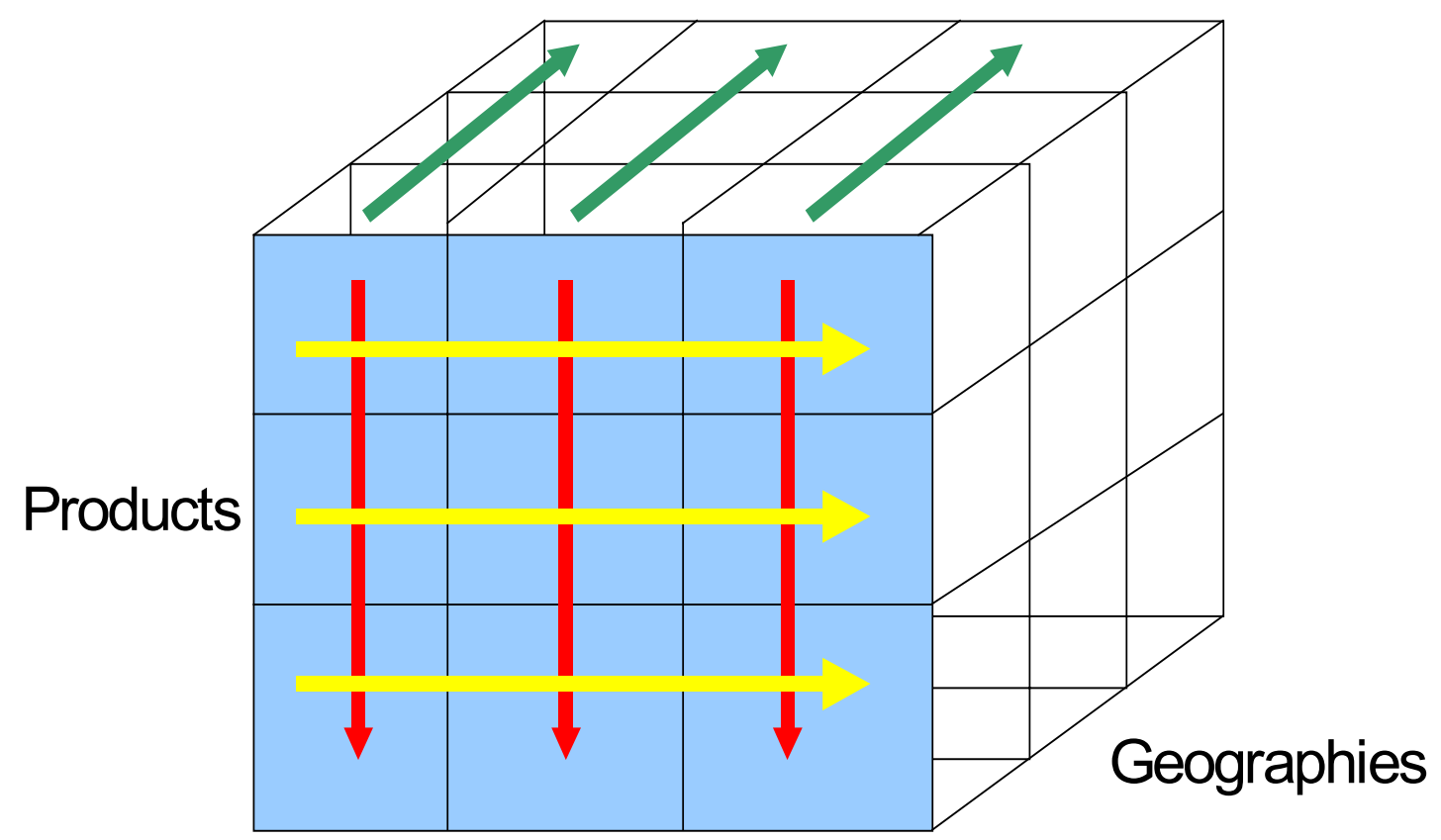

Client Segments 


\section{Exhibit 3}

Importance of Lending to Earn M\&A Business*

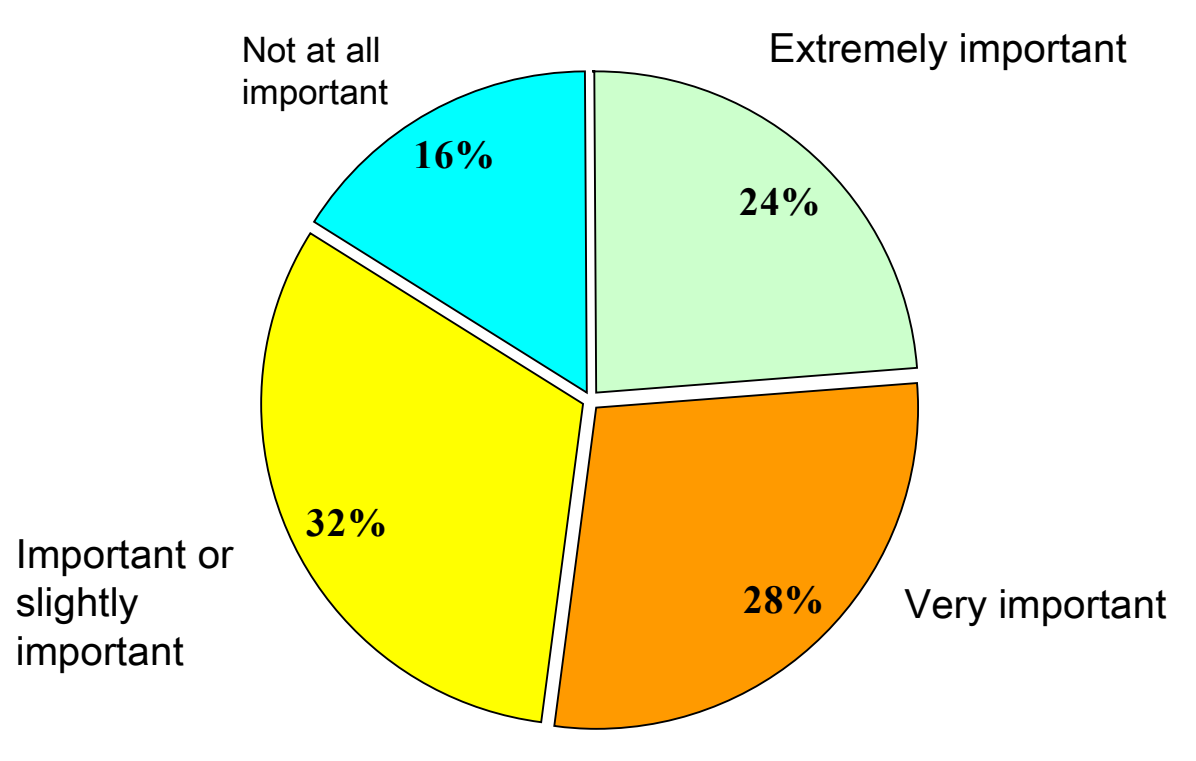

*Base: 626 US Companies

Source: Greenwich Associates, 2001 
Exhibit 4

Comparative Wholesale Banking Volumes, Top-12 Firms

Bank

- Citigroup

Goldman, Sachs

Morgan Stanley

Merrill Lynch

- Credit Suisse First Boston

Lehman Brothers

- J.P. Morgan Chase

Bank of America Sec.

- UBS Warburg

- Deutsche Bank

- Dresdner Kleinwort Wasserst.

Barclays

= Wholesale banking units of universal

banks or financial conglomerates.

\section{0}

Wholesale

Banking

Volume

$1,236,248$
$1,268,177$
$1,283,288$
$1,163,164$
$1,085,050$
418,807
$1,295,220$
483,986
481,574
409,417
448,538
162,425

2001

Wholesale

Banking

Volume

$$
\begin{array}{r}
1,873,452 \\
1,462,301 \\
1,422,292 \\
1,672,698 \\
1,212,275 \\
864,778 \\
1,794,838 \\
664,468 \\
967,104 \\
917,702 \\
540,445 \\
406,207
\end{array}
$$

2001

Market

Share

$\begin{array}{rr}10.81 \% & 1 \\ 8.43 \% & 4 \\ 8.20 \% & 5 \\ 9.65 \% & 3 \\ 6.99 \% & 6 \\ 4.99 \% & 9 \\ 10.35 \% & 2 \\ 3.83 \% & 10 \\ 5.58 \% & 7 \\ 5.29 \% & 8 \\ 3.12 \% & 11 \\ 1.41 \% & 12\end{array}$

2001

Rank

Wholesale banking volume comprises loan syndications (full credit to lead manager, debt and equity underwriting (full credit to bookrunner, Medium -term notes (full credit to dealer) and M\&A advisories (full credit to lead adviser). Data: Thomson Financial Securities Data Platinum. 


\section{Exhibit 5}

Prototype On-Line Personal Finance Platform

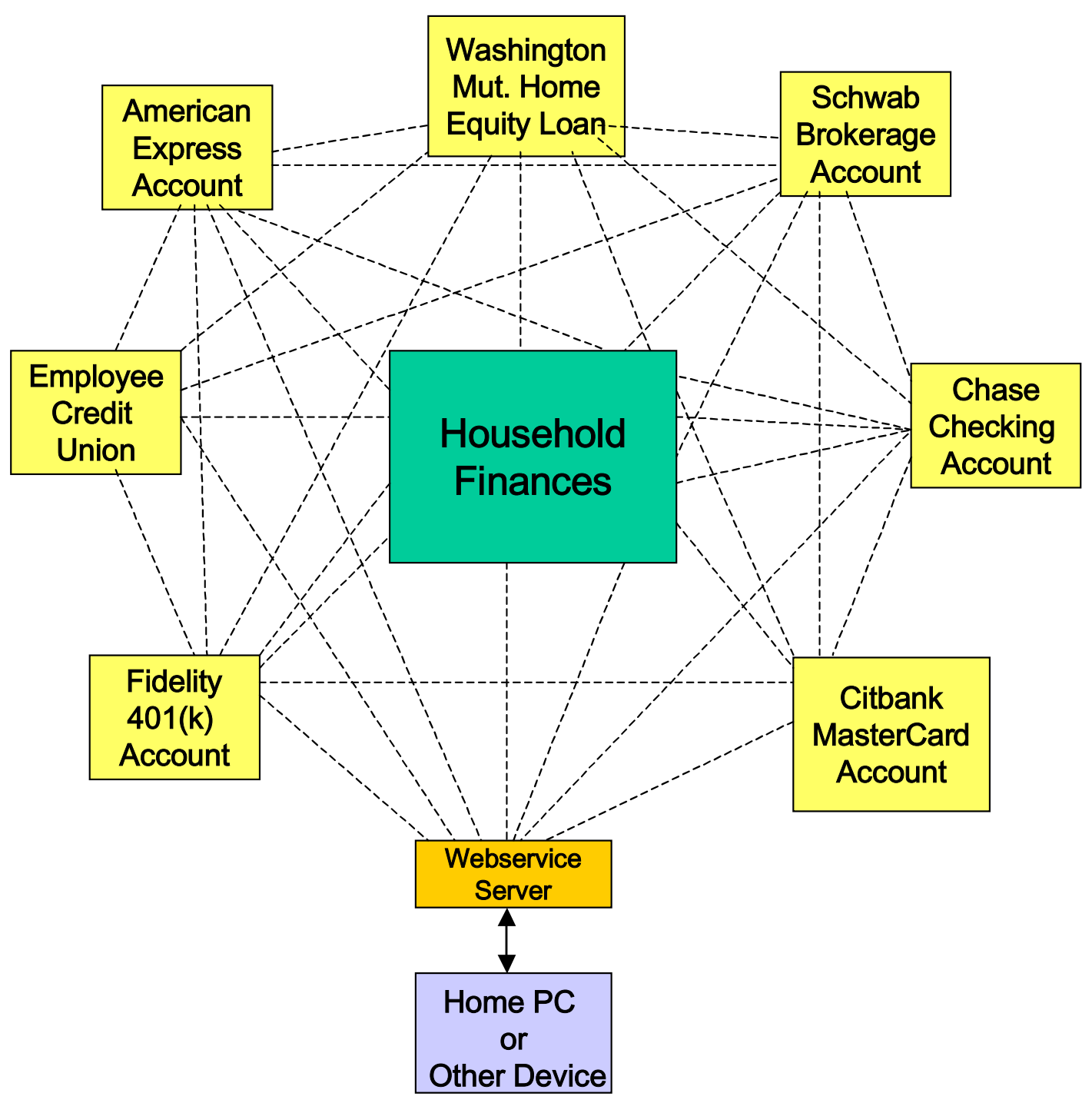




\section{Exhibit 6 \\ Indicative Financial Services Conflict Matrix}

Commercial lender

Loan arranger

Debt underwriter

Equity underwriter

M\&A advisor

Strategic financial advisor

Equity analyst

Debt analyst

Board member

Institutional asset manager

Mutual fund distributor

Stockbroker

Private banker

Retail lender

Credit card issuer

Information processor

Transactions processor

Clearance \& settlement

Custodian

Life insurer

P\&C insurer

Reinsurer

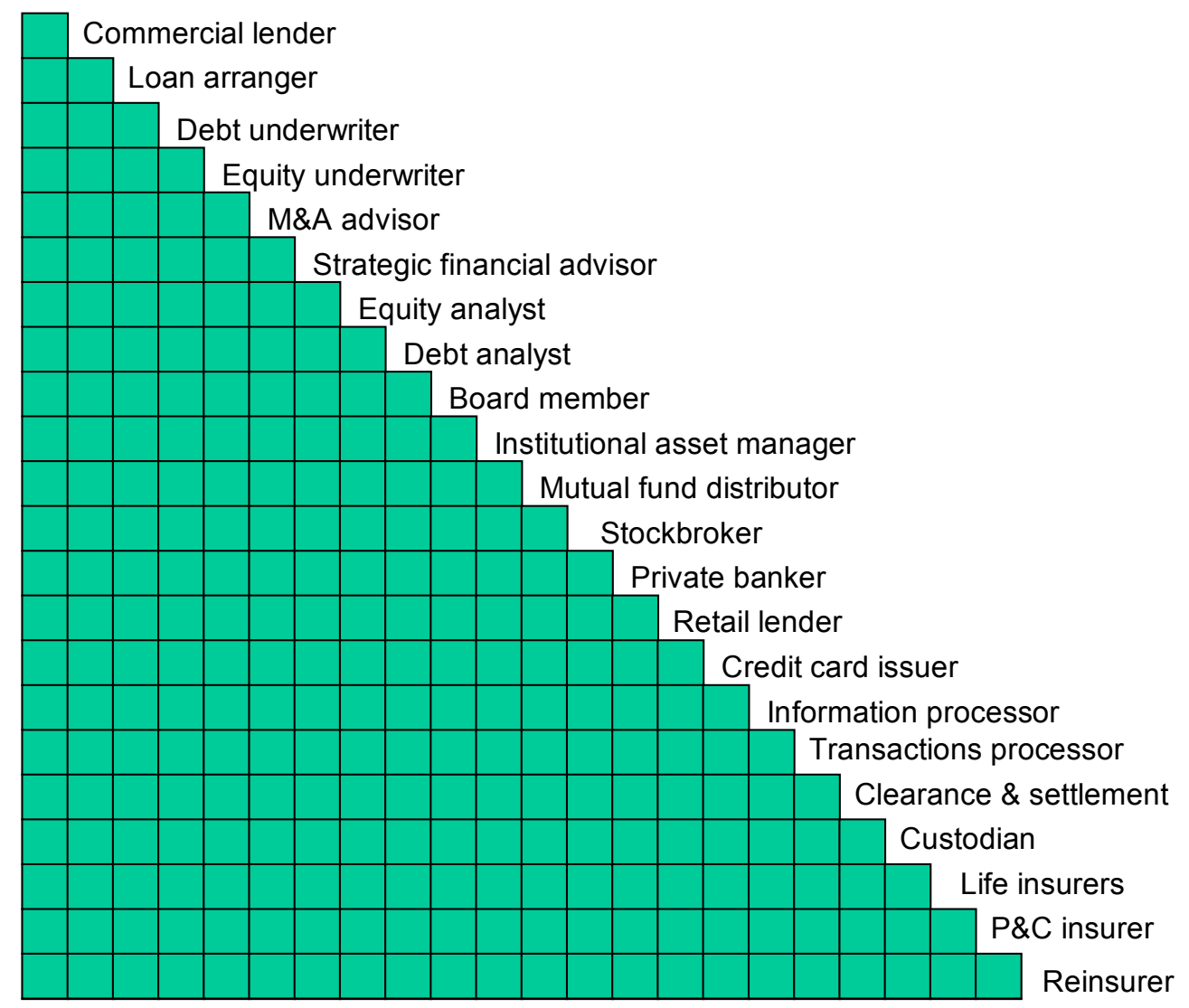




\section{Exhibit 7}

\section{Comparative Share Prices, Citigroup and JP Morgan Chase}

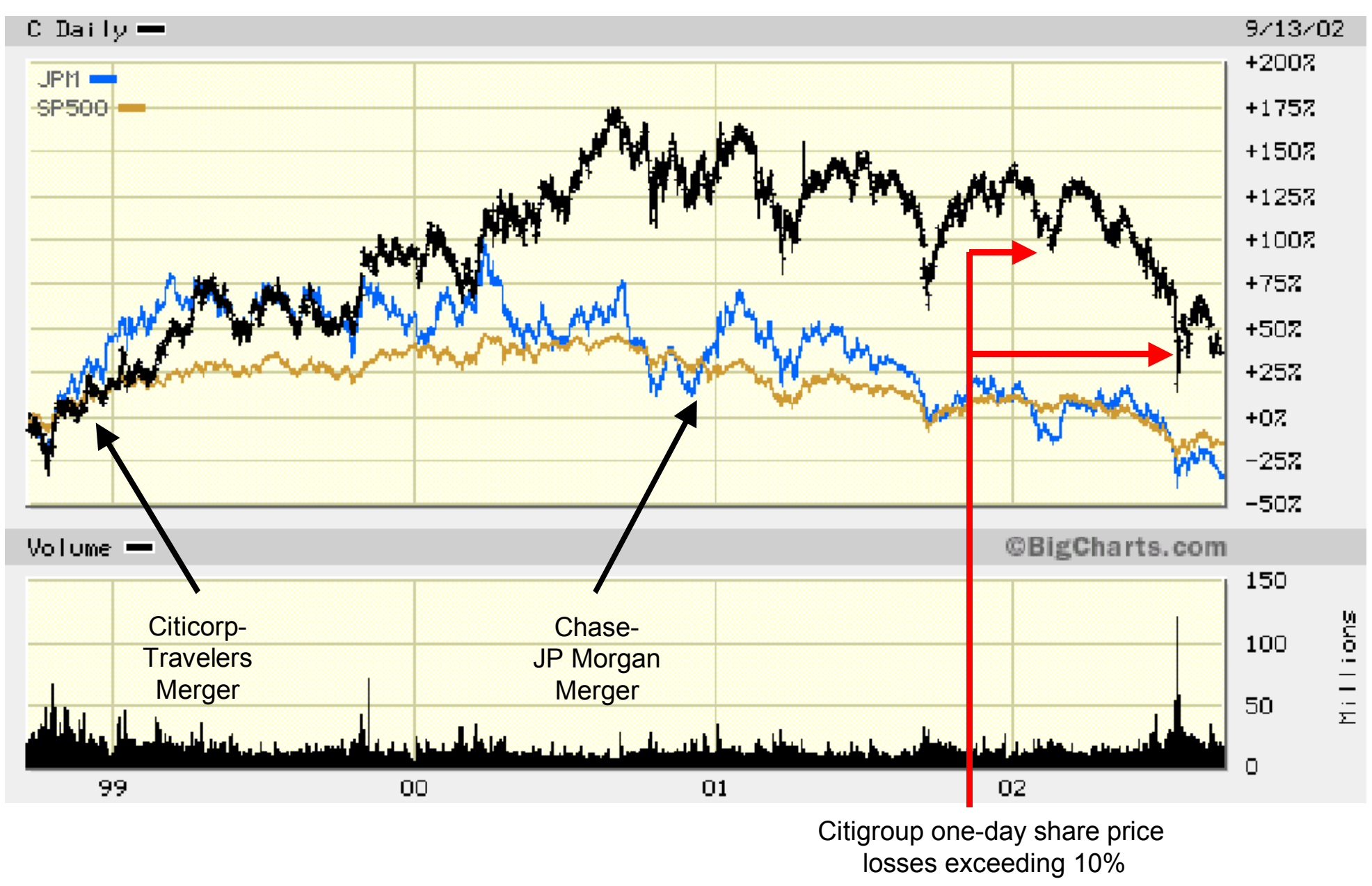


Exhibit 8

Valuation Gains and Losses Attributable to Size an Scope

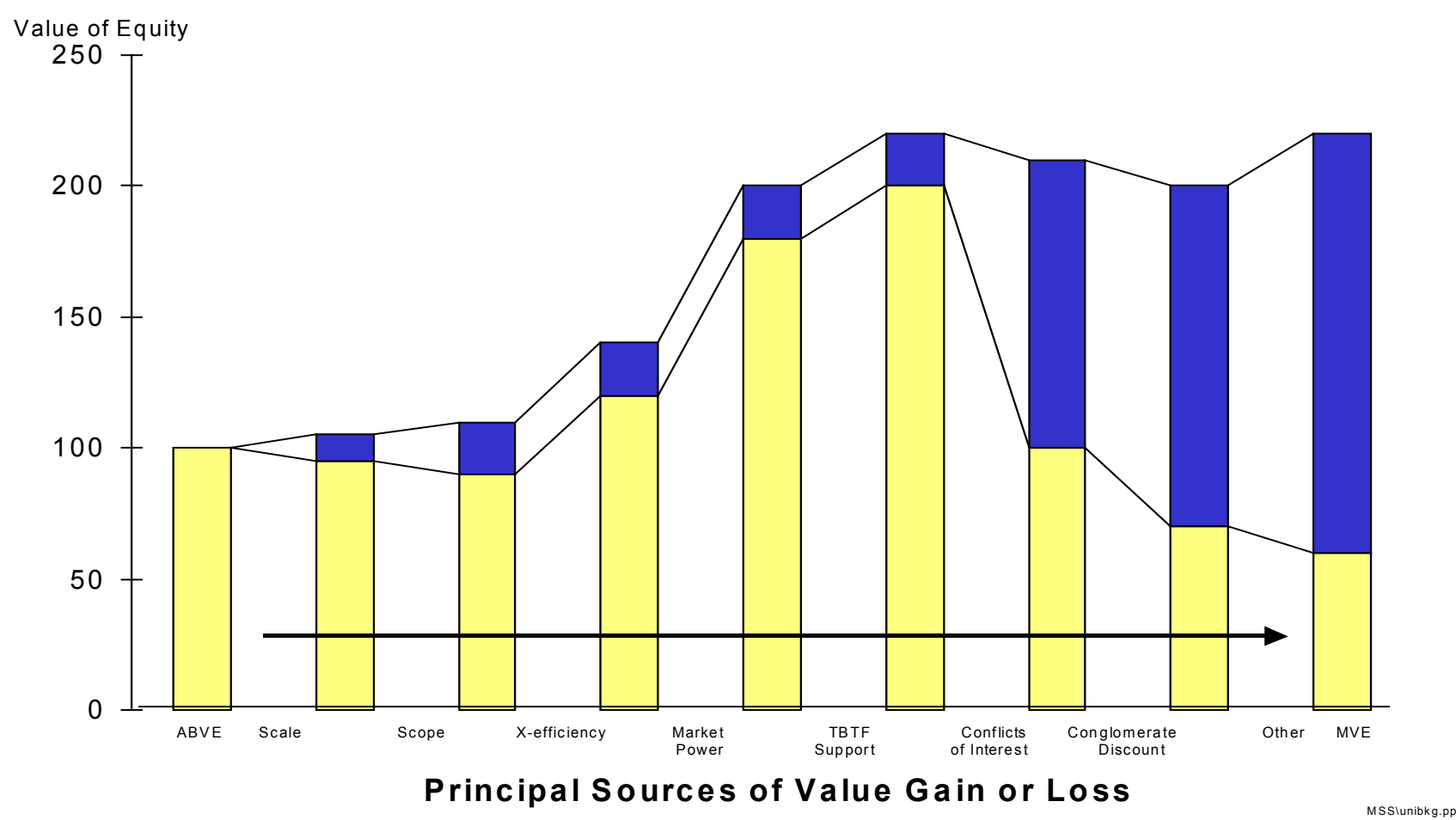


Exhibit 9

THE 15 MOST VALUABLE FINANCIAL SERVICES BUSINESSES IN NORTH AMERICA AND EUROPE 1

(market capitalization in US \$ million, July 2002)

\section{NORTH AMERICA}

Citigroup

AIG

GECS

Bank Of America

Berkshire Hathaway

Fifth Third Bancorp

J P Morgan Chase

American Express

Wachovia

Morgan Stanley

Banc One

Wells Fargo

U.S. Bancorp

Washington Mutual

Fleet Boston
223.04

174.09

155.74

117.09

114.36

89.64

71.55

57.00

52.49

50.00

47.70

45.29

37.93

37.84

36.99

\section{EUROPE}

HSBC

RBS Group

116.34

UBS AG

83.40

69.56

Lloyds TSB Group

60.25

Barclays

57.42

Allianz AG

54.66

ING

52.70

BNP Paribas

49.92

Deutsche Bank AG

44.86

CS Group

44.14

44.06

41.39

Munich Re

38.55

BBVA

31.56

Swiss Re

30.56

${ }^{1}$ Source: Business Week, July 15, 2002 


\section{References}

Akhavein, Jalal D., Allen N. Berger and David B. Humphrey, "The Effects of Megamergers on Efficiency and Prices: Evidence From a Bank Profit Function," Review of Industrial Organization, 12, 1997.

Beatty, R., A. Santomero, and M. Smirlock, "Bank Merger Premiums: Analysis and Evidence," New York University Salomon center for the Study of Financial Institutions Monograph Series on Economics and Finance, 3, 1987.

Berger, Allen N., Rebecca S. Demsetz and Philip E. Strahan, The Consolidation of the Financial Services Industry: Causes, Consequences, and Implications for the Future (New York: Federal Reserve Bank of New York, 1998).

Berger, Allen N., Diana Hancock and David B. Humphrey, "'Bank Efficiency Derived from the Profit Function," Journal of Banking and Finance, April 1993.

Berger, Allen N. and T.H. Hannan, "Using Measures of Firm Efficiency to Distinguish Among Alternative Explanations of the Structure-Performance Relationship," Managerial Finance, October 1996.

Berger, Allen N. and David B. Humphrey, "Megamergers in Banking and the Use of Cost Efficiency as an Antitrust Defense," The Antitrust Bulletin, 37, 1992B.

Berger, Allen N., William C. Hunter and Stephen J. Timme, "The Efficiency of Financial Institutions: A Review of Research Past, Present and Future," Journal of Banking and Finance, April 1993.

Berger, Allen N. and L. Mester, "Inside the Black Box: What Explains Differences in the Efficiencies of Financial Institutions?" Journal of Banking and Finance, 21, 1997.

Berger, Philip G. and Eli Ofek, "Diversification's Effect on Firm Value," Journal of Financial Economics, 37, 1995.

Boyd, John, Stanley Graham, and R. S. Hewitt, "Bank Holding Company Mergers with Non-bank Financial Firms: Effects on the Risk of Failure," Journal of Financial Economics, 17, 1993.

Brown, Stephen J. and Jerold B. Warner "Using Daily Stock Returns: The Case of Event Studies," Journal of Financial Economics, 14, 1985.

Cummins, J.D. and H. Zi, "Comparisons of Frontier Efficiency Levels," Journal of Productivity Analysis, June 1998. 
DeLong, Gayle, "Stockholder Gains From Focusing Versus Diversifying Bank Mergers," Journal of Financial Economics, 59, 2001B.

Demsetz, Rebecca S., Marc R. Saidenberg and Philip E. Strahan, "Banks with Something to Lose: The Disciplinary Role of Franchise Value," Federal Reserve Bank of New York Policy Review, October 1996.

Goldberg, L.G., G.A. Hanweck, M. Keenan and A. Young, "Economies of Scale and Scope in the Securities Industry," Journal of Banking and Finance, 15, 1991.

Houston, J., C. James, and M. Ryngaert, "Where Do Merger Gains Come From? Bank Mergers From the Perspective of Insiders and Outsiders," Working Paper, University of Florida, Gainesville, 1999.

Houston, J. and M. Ryngaert, "The Overall Gains From Large Bank Mergers," Journal of Banking and Finance, 18, 1994.

John, Kose and Eli Ofek, "Asset Sales and Increase in Focus," Journal of Financial Economics, 37, 1995.

Kane, E., "Incentives for Banking Megamergers: What Motives Might Regulators Infer from Event-Study Evidence?" Journal of Money, Credit, and Banking, Vol. 32, August, 2000.

Kroszner, R. and R. Rajan, "Is the Glass-Steagall Act Justified? A Study of the U.S. Experience with Universal Banking Before 1933," American Economic Review, 84, 1994.

Lang, G. and P. Wetzel, "Technology and Cost Efficiency in Universal Banking: A Thick Frontier Approach," Journal of Productivity Analysis, 10, 1998.

O'Hara, M. and W. Shaw, “Deposit Insurance and Wealth Effects: The Value of Being 'Too Big to Fail”' Journal of Finance, 45, 1990.

Puri, M. "Commercial Banks in Investment Banking: Conflict of Interest or Certification Role?" Journal of Financial Economics, 40, 1996.

Santomero, A. and E. J. Chung, "Evidence in Support of Broader Bank Powers," Financial Markets, Institutions, and Instruments, 1, 1992.

Saunders, Anthony, Financial Institutions Management: A Modern Perspective, Third 
Edition (Burr Ridge, III.: Irwin, 2000).

Saunders, Anthony and Ingo Walter, Universal Banking in the United States (New York: Oxford University Press, 1994).

Siems, Thomas F. "Bank Mergers and Shareholder Value: Evidence from 1995's Megamerger Deals," Federal Reserve Bank of Dallas Financial Industry Studies, August 1996.

Smith, Roy C. and Ingo Walter, "JP Morgan and Banco Español de Crédito: Teaching Note", Case Studies in Finance and Economics, Second Edition C53, New York University Salomon Center, 1995.

Smith, Roy C. and Ingo Walter, Street Smarts: Leadership and Shareholder Value in the Securities Industry (Boston: Harvard Business School Press, 1997).

Smith, Roy C. and Ingo Walter, Global Banking, Second Edition (New York: Oxford University Press, 2003).

Stefanadis, Chris, "Specialist Securities Firms in the Gramm-Leach-Bliley Era. Federal Reserve Bank of New York. Working Paper, 2002.

US General Accounting Office, "Deposit Insurance: overview of Six Foreign Systems" Washington, D.C.: GAO/NSIAD-91-104, 1991.

Walter, Ingo (1988). Global Competition in Financial Services (Cambridge: BallingerHarper \& Row, 1998).

Walter, Ingo, "Universal Banking: A Shareholder Value Perspective," Schriftenreihe des Instituts fuer Kapitalmarktforschung as der Johann Volfgang Goethe-Universitaet, Frankfurt am Main, Germany, 42, 1998.

Walter, Ingo (2003). "Mergers and Acquisitions in Banking and Finance - Where's the Value? (New York: Oxford University Press, 2003).

$\mathrm{Yu}$, L. "On the Wealth and Risk Effects of the Glass-Steagall Overhaul: Evidence from the Stock Market," Working Paper, New York University, 2001. 